\title{
Are mTOR and Endoplasmic Reticulum Stress Pathway Genes Associated with Oral and Bone Diseases?
}

\author{
Mariana Bezamat ${ }^{a} \quad$ Kathleen Deeley $^{a}$ Shahryar Khaliq ${ }^{a}$ Ariadne Letra $^{a} \mathrm{~d}$ \\ Rafaela Scariot $^{\mathrm{a}-\mathrm{c}}$ Renato M. Silva ${ }^{\mathrm{a}} \mathrm{d}$ Megan L. Weber ${ }^{\mathrm{a}}$ Diego G. Bussanelia, e \\ Paula C. Trevilatto ${ }^{b}$ Alejandro J. Almarza ${ }^{a}$ Hongjiao Ouyang $^{f} \quad$ Alexandre R. Vieira $^{a}$ b \\ ${ }^{a}$ Department of Oral Biology, University of Pittsburgh, Pittsburgh, PA, USA; ${ }^{b}$ Graduate Program of Health Sciences, \\ PUC-Paraná, Curitiba, Brazil; ' $D$ Department of Oral Surgery, Positivo University, Curitiba, Brazil; ${ }^{d}$ Department of Endodontics, \\ University of Texas Health Sciences Center at Houston, Houston, TX, USA; ${ }^{e}$ Department of Pediatric Dentistry, UNESP,

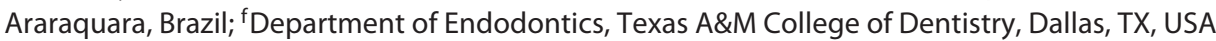

\section{Keywords}

Dental caries · Periodontitis · Endodontics · Osteoporosis ·

Endoplasmic reticulum stress $\cdot \mathrm{mTOR}$ signaling

\begin{abstract}
The purpose of this cohort study was to identify associations between combined oral and bone disease phenotypes and genes present in cell regulatory pathways. The studied pathways play important roles in cellular growth, proliferation, differentiation, and homeostasis. DNA samples extracted from whole saliva of 3,912 individuals were genotyped and these data analyzed according to dental caries experience, periapical lesions, periodontitis, osteoporosis, or temporomandibular joint discomfort. Samples were obtained from the Dental Registry and DNA Repository project at the University of Pittsburgh. Twenty-seven polymorphisms in eight genes related to mTOR or endoplasmic reticulum stress pathways were selected for genotyping. Allele frequencies and Hardy-Weinberg equilibrium were calculated. Analyses were performed comparing genotypes between affected and unaffected individuals for each phenotype, as well as for the associated phenotypes combined. For all analyses, we used the software PLINK with an alpha of 0.002. Borderline associations with multiple variants of several genes were
\end{abstract}

found, suggesting that both pathways may be involved in the susceptibility to multiple conditions affecting the oral cavity and bones. When combining patients that had concomitant dental caries, periodontitis, and periapical pathology, several markers in RHEB showed statistically significant association. Multiple conditions affecting bone and teeth (i.e., dental caries, periodontitis, periapical lesion formation, and osteoporosis) appear to share similar underlying genetic etiological factors, which allow us to hypothesize that instead of individually, they should be studied in conjunction in human populations.

๑) 2018 S. Karger AG, Basel

\section{Introduction}

Poor oral health continues to be a reason for developing health policies that protect those most susceptible in populations and enhance preventive strategies. Since the most common of these conditions (i.e., dental caries and periodontitis) are bacteria-mediated affections, water fluoridation, and oral hygiene-based preventive strategies are justified. Furthermore, individuals affected by these common conditions commonly develop additional health problems. Symptoms for these distinct conditions can be similar, such as developing discomfort, pain, and inflam-

\section{KARGER}

(c) 2018 S. Karger AG, Basel

E-Mail karger@karger.com

www.karger.com/cre
Alexandre R. Vieira

Department of Oral Biology, 412 Salk Pavilion

School of Dental Medicine, University of Pittsburgh

335 Sutherland Drive, Pittsburgh, PA 15261 (USA)

E-Mail arv11@ pitt.edu 
mation. Overtime, the chronic character of dental caries and periodontitis creating a chronic inflammatory state can lead to inadequate amino acid supply, which leads to reduced protein synthesis and degradation [Mercier et al., 2002]. With that concept in mind, we believe that certain pathways will be associated with multiple conditions, for instance pathways related to protein synthesis.

Mammalian target of rapamycin $(m T O R)$ signaling is a master regulator of protein synthesis. Tuberous sclerosis 1 and 2 (TSC1 and TSC2) are two tumor suppressor genes that when activated repress $m$ TOR function. When TSC1 and TSC2 are defective, like in the tuberous sclerosis complex, these two genes lose their function, leading to hypermineralization of bones. MTOR signaling is comprised of two complexes - mTORC1 and mTORC2; the first is a center regulator for protein synthesis and the second is a center regulator for the serine/threonine kinase (AKT) in the cell. RHEB (Ras homolog enriched in brain) is a positive regulator for both $m$ TORC1 and $m$ TORC2, but its function is repressed by TSC1 and TSC2 [Brown et al., 1994]. Activation of the $m$ TOR signaling by alcohol use can inhibit odontogenic differentiation of human dental pulp cells [Qin et al., 2017]. When mTOR signaling is inhibited, there is an alleviation of the inflammatory response to periodontal pathogens such as Porphyromonas gingivalis [Xia et al., 2017], what leads us to believe that variation in $m$ TOR signaling genes will play a role in the periodontal disease outcomes.

The other genes that we looked for association in this present study are genes that influence the endoplasmic reticulum stress (ER stress). ER stress is a phenomenon that occurs when signals emanating from the ER induce a transcriptional program that enables cells to survive the stress generated by an elevated amount of protein synthesized [Schonthal, 2012]. When affected cells sense there is ER stress, three signal pathways can be activated: ER transmembrane inositol-requiring enzyme-1 (ERN1) $\alpha$ and $\beta$, protein kinase-like ER kinase [Reimold et al., 2000], and activating transcription factor 6 (ATF6). Collectively, these pathways can restore intracellular homeostasis. This coordinated response, the unfolded protein response, facilitates the folding, processing, export, and degradation of proteins emanating from the ER during stressed conditions [Ron and Walter, 2007]. ERN1 is an ER membrane domain, which has a dual function of making apoptosis and serving as an endoribonucleous. ERN1 splices a 26-base pair sequence of Xbp1 [Yoshida et al., 2001]. Xbp1 can control many genes that are involved in the biogenesis of ER as well as protein folding. In addition, $X b p 1$ expression was also demonstrated to play a role in ameloblast ER volume during enamel formation [Tsuchiya et al., 2008]. This pathway is essential to maintain intracellular homeostasis. The conditions we are studying here are complex with variable levels of genetic influences that modulate both the development of underlying affected structures and active protein synthesis, including folding and transport, whose mechanisms are not well understood with regard to pathogenesis of each disease.

In this present study, we tested the hypothesis that variations in genes belonging to the $m$ TOR and ER stress pathways may play a role in oral/bone diseases such as dental caries, periodontitis, periapical pathology, osteoporosis, and temporomandibular joint discomfort. We believe that genetic variation in the selected genes will disrupt protein synthesis, affect bone metabolism, and influence chronic inflammatory states.

\section{Materials and Methods}

We selected 27 markers in eight genes of the mTOR and ER stress pathways to be tested in five oral/bone disease phenotypes (dental caries, periapical lesions due to deep caries lesions in dentin, periodontitis, osteoporosis, and temporomandibular joint symptoms), described in detail below. In this cohort study, a dataset consisting of DNA samples from 3,912 unrelated subjects who sought treatment at the University of Pittsburgh dental clinics was utilized. Individual samples and clinical history were obtained through the Dental Registry and DNA Repository of the School of Dental Medicine, University of Pittsburgh. Subjects' mean age was $40.9 \pm 19.3$ years (ranging from 6 to 92 years old). This project has the approval of the University of Pittsburgh Institutional Review Board (IRB \#0606091). Written informed consent documents were obtained from all subjects. Age-appropriate assent documents were used for children between 6 and 14 years and signed informed consent documents were obtained from the parents. For all comparisons described below, there were no significant differences in the distribution of ages and the frequency of Whites and Blacks between the two comparison groups (data not shown). This article follows the STROBE guidelines for reporting observational studies.

\section{Phenotypes and Sample Selection}

One of the authors (M.B.) carried out the extraction of clinical data after being calibrated by an experienced specialist (A.R.V.). The clinical data included the complete oral conditions and treatments present in the database for each of the patients seeking care between September 2006 and January 2013. The intraexaminer agreement was assessed by a second extraction of clinical data in $10 \%$ of the sample after 2 weeks, with a kappa of 1.0. Since each phenotype studied is recovered from a registry of clinical information derived from the dental clinics of the University of Pittsburgh, calculating inter- or intraexaminer agreement is not possible. All phenotypes are recorded following the same guidelines by students in training under the supervision of experienced dental professionals who are calibrated annually.

\section{Dental Caries}

We selected 1,481 samples (715 males and 766 females) to evaluate the dental caries phenotype. The presence and severity of den- 
tal caries was taken into consideration, and we used the DMFT (decayed, missing due to caries and filled teeth) score to assign individuals to one of the comparison groups. The population was classified as either having "less severe" $(n=553)$ or "more severe" $(n=853)$ caries experience, based on DMFT/dmft distribution (DMFT/dmft mean and standard deviation) and subject's age. The mean DMFT score was 15.9 with a standard deviation of 8.7 and ranged from 0 to 28 . The criteria used here for classification of caries experience took age into consideration, since it is expected that caries experience will increase in the general population with age [Liss et al., 1982]. The water in the Pittsburgh area is artificially fluoridated. Table 1 describes the criteria for defining individuals with higher or lower caries experience. This study sample was previously described [Kuchler et al., 2014].

Power calculations [Purcell et al., 2003], assuming that our marker alleles were in complete linkage disequilibrium with the genetic variant contributing to caries susceptibility, and that the chance of having a distinct (very low or very high) caries susceptibility increased two and a half-fold when having one copy of the caries susceptibility allele, suggested a $92 \%$ power to detect a possible association with our sample size. This procedure was for a marker B in linkage disequilibrium with our test locus A. Other parameters specified in the calculations were the high-risk allele frequency for the allele A (set at 0.1 ), the disease prevalence in the general population (set at 0.5 , corresponding to the approximate frequency of caries-free individuals or highly affected individuals $[\mathrm{DMFT}=20]$ ), and the genotype risks for the Aa and AA genotypes relative to the baseline aa genotype risk. We used most of the same power parameters for all five phenotypes (dental caries, periodontitis, periapical pathology, osteoporosis, and temporomandibular joint discomfort).

Periapical Lesions due to Deep Caries Lesions in Dentin

Sixteen hundred radiographic records were screened for subjects with deep carious lesions in dentin with or without periapical lesions ( $\geq 3 \mathrm{~mm}$ in diameter). The criteria used to select the affected group was the presence of both deep carious lesions and periapical lesions (110 individuals, 57 males and 53 females with an average age of 57 years and a standard deviation of 10 years) and for comparison, we selected a group in which they had the presence of deep carious lesions but absence of periapical lesions (158 individuals, 65 males and 93 females with an average age of 58 years and a standard deviation of 8 years). This cohort of a total of 268 samples has been previously reported [Menezes-Silva et al., 2012]. We estimated to have $85 \%$ power to detect an association with the studied sample size. The disease prevalence in the general population was set at 0.5 , corresponding to the approximate frequency of deep caries lesions and absence of periapical lesions in the study sample.

\section{Periodontitis}

Individuals were considered affected if presenting at least three teeth exhibiting sites of clinical attachment loss equal to or greater than $5 \mathrm{~mm}$ in two different quadrants (61 individuals, 22 males and 39 females). For comparison, we selected individuals showing absence of clinical attachment loss and no sites with probing depth greater than $3 \mathrm{~mm}$ (325 individuals, 144 males and 181 females) totalizing 386 samples selected for genotyping (average age was 50 years with a standard deviation of 8 years). This sample has been previously described [Letra et al., 2012]. Considering a prevalence of periodontitis of $60 \%$, a power of $80 \%$ was estimated for this phenotype in our study sample.

Association between Cell Homeostasis Genes and Oral Diseases
Table 1. Definition of caries experience based on age and DMFT (decayed, missing due to caries and filled teeth) scores $(n=1,481)$

\begin{tabular}{|c|c|c|}
\hline Caries experience level & $\mathrm{DMFT} / \mathrm{dmft}$ & Sample \\
\hline \multicolumn{3}{|c|}{ Children and teenagers (from 6 to 19 years of age) } \\
\hline Less severe caries experience & $0-3$ & 73 \\
\hline More severe caries experience & 4 or higher & 138 \\
\hline \multicolumn{3}{|c|}{ Young adults (from 20 to 39 years of age) } \\
\hline Less severe caries experience & $0-10$ & 215 \\
\hline More severe caries experience & 11 or higher & 241 \\
\hline \multicolumn{3}{|c|}{ Middle age (from 40 to 59 years of age) } \\
\hline Less severe caries experience & $0-15$ & 152 \\
\hline More severe caries experience & 16 or higher & 384 \\
\hline \multicolumn{3}{|l|}{ Elderly (60 years of age and older) } \\
\hline Less severe caries experience & $0-20$ & 95 \\
\hline More severe caries experience & 21 or higher & 183 \\
\hline
\end{tabular}

The thresholds were defined based on the DMFT distribution in the studied group by age [Kuchler et al., 2014].

\section{Osteoporosis}

Twenty-two cases of osteoporosis/osteopenia were identified (20 females and 2 males, mean age of 62 years), and 553 unaffected individuals older than 50 years of age ( 221 men, 332 women, mean age of 68 years) were selected to serve as comparison. None of the selected cases had periodontitis, but 7 of those had dental caries and were part of the dental caries group described above as well. We estimated power as $43 \%$ with the sample size we had. The prevalence of osteoporosis was set at 0.55 , according to the May 2018 Interdisciplinary Symposium on Osteoporosis (nof. org).

Temporomandibular Joint Symptoms

We selected 1,202 women in childbearing age, 521 with a record of, at least, one symptom in the temporomandibular joint (clicks, sounds, or pain) and 681 without any symptoms that were used for comparison. Their mean age was 35.3 years, ranging from 15 to 55 years. Power was estimated as $100 \%$ to detect a possible association with the studied sample size. The disease prevalence in the general population was set at 0.5 .

\section{Combined Phenotypes}

We followed the European Federation of Periodontology (EFP) and European Organization for Caries Research (ORCA) joint recommendation and analyzed dental caries combined with periodontitis within the same individuals [Chapple et al., 2017]. In addition, we analyzed dental caries combined with periapical pathology and caries combined with periodontitis and periapical pathology. Osteoporosis and temporomandibular joint symptoms were excluded from this analysis since only 22 cases with confirmed osteoporosis/osteopenia were available, and for temporomandibular joint symptoms no formal significant associations with the selected genes were found.

We excluded 24 participants that had missing information about the presence of periodontitis or periapical pathology since 
those conditions were taken into consideration for the combined analyses. We found that 794 individuals had periodontitis and recorded caries experience (high caries experience, 174 females and 149 males; low caries experience, 229 females, 242 males), 433 had periapical pathology and recorded caries experience (high caries experience, 57 females and 63 males; low caries experience, 158 females, 155 males), and 234 have periodontitis, periapical pathology and high caries experience (high caries experience, 31 females and 48 males; low caries experience, 90 females, 107 males). Combining the disease phenotypes aims to generate a more homogeneous group.

\section{Selection of Genes and Single Nucleotide Polymorphisms}

Since RHEB is a molecule located at the center of the mTOR pathway and can be repressed by TSC1 and 2, we choose genes immediately up and downstream of RHEB. RHEB's role also impacts ER stress [Fan et al., 2017]. Twenty-seven single nucleotide polymorphisms (SNPs) in eight genes were selected (ERN1 - rs196929, rs196950, rs11655020, rs16947425, and rs1874087; XBP1 - rs2097461 and rs2239815; RPTOR - rs2289764, rs1012117, rs11651724, rs4255830, and rs4396582; TSC1 - rs1050700; TSC2 - rs1051771, rs7187438, and rs2073636; RHEB - rs3753151, rs2299967, rs2374261, and rs1109089; RICTOR - rs1239265, rs13166875, rs1423688 and rs2043112; and $m$ TOR - rs11580061, rs1010447, and rs11121718). We prioritized genes to be studied considering: Fan group's previous reports of expression in diseased tissues, and their previous reports of association with bone diseases [Fan et al., 2017]. In the case of temporomandibular joint symptoms, four polymorphisms were tested in ERN1 (rs11655020, rs1874087, rs196950, and rs196929) and two in XBP1 (rs2097461 and rs2239815).

SNPs were selected based on published reports and/or their locations in the genes, based on their likelihood to have functional consequences (i.e., located in promoter regions, exons, or near exon/intron boundaries), or if considered tag SNPs as surrogates for the linkage disequilibrium blocks surrounding the gene of interest. We used information from the NCBI dbSNP (http://www. ncbi.nlm.nih.gov/snp) and the HapMap Project (http://www.hapmap.org) databases for selecting SNPs to be studied.

\section{Genotyping}

Genomic DNA was extracted from whole saliva using established protocols. Genotypes were generated blindly to clinical diagnosis status. Reactions were carried out using Taqman chemistry [Ranade et al., 2001] in volumes of $3.0 \mu \mathrm{L}$ in an ABI PRISM Sequence Detection System 7900 (Applied Biosystems, Foster City, CA, USA). Applied Biosystems supplied assays and reagents. The results were analyzed using SDS software version 1.7 (Applied Biosystems). PCR reactions were repeated twice when necessary.

\section{Data Analyses}

Allele frequencies and Hardy-Weinberg equilibrium were calculated. Association analyses were performed comparing genotypes between affected individuals and their respective comparison group as implemented in PLINK [Purcell et al., 2007]. $p$ values below 0.002 $(0.05 / 27$; the denominator is the number of genetic markers tested) were considered statistically significant. Additional analysis was performed combining patients that have more than one oral disease phenotype (periodontitis, periapical pathology, and caries experience), as well as the three oral phenotypes combined.

\section{Results}

We found nominal associations between each of the five phenotypes studied and mTOR or ER stress genes (Table 2). Significant associations were found between periapical lesions due to deep caries lesions in dentin and RHEB ( $p=0.0002)$, osteoporosis/osteopenia and $m$ TOR $(p=6.0 \mathrm{E}-8), R A P T O R(p=0.002), R I C T O R(p=0.001)$, ERN1 $(p=5.0 \mathrm{E}-5)$, and TSC2 $(p=4.0 \mathrm{E}-5)$, and dental caries and RPTOR $(p=0.0008)$. When combining patients that had concomitant dental caries, periodontitis, and periapical pathology, several markers in RHEB showed association (Table 3).

\section{Discussion}

Although caries is mostly a preventable disease, it is still very common all over the world. Many factors can play a role in the dental caries phenotype, such as the high level of consumption of sugar and carbs, the oral microbiota, exposure to fluorides from the drinking water and/ or dentifrices, and poor oral hygiene. Even though all these factors contribute to the disease development, evidence suggests that individual genetic variation plays a role in the disease process as well [Vieira et al., 2012].

The genetic factors related to the host, which are represented by genes involving enamel formation, saliva composition, dietary preferences, and immune response [Shuler, 2001], can be involved in caries susceptibility. Genes in the mTOR (mammalian target of rapamycin) pathway are involved in dental mineralization [Kim et al., 2011] and hence could contribute to caries susceptibility. In addition, fluoride induces ER stress and interferes with enamel proteinase secretion [Wei et al., 2013], which may result in alterations of the enamel that can modify individual caries susceptibility.

$m T O R C 1$ is a ternary complex containing $m T O R$, $R A P T O R$ (Regulatory Associated Protein of $m T O R$ ) and G-BetaL. MTORC1 regulates VEGF (vascular endothelial growth factor) by inducing HIFla [Brugarolas et al., 2003]. The association between genetic variation in $R A P$ $T O R$ and cases with more severe caries experience may be related to a mechanism that involves individuals more susceptible to caries lesion progression in enamel and dentine.

When the caries phenotype is defined as having caries or not having caries, DMFT score 0 versus DMFT score 1 or higher, it may not be feasible to detect genes that may contribute to the severity of the disease. This is probably 
Table 2. Summary results highlighting nominal (between 0.05 and 0.0025$)$ and statistically significant $(\leq 0.002$, marked in bold) $p$ values for allele and genotype association analyses between periapical lesions, periodontal disease, osteoporosis, dental caries experience, and temporomandibular joint symptoms and the evaluated markers

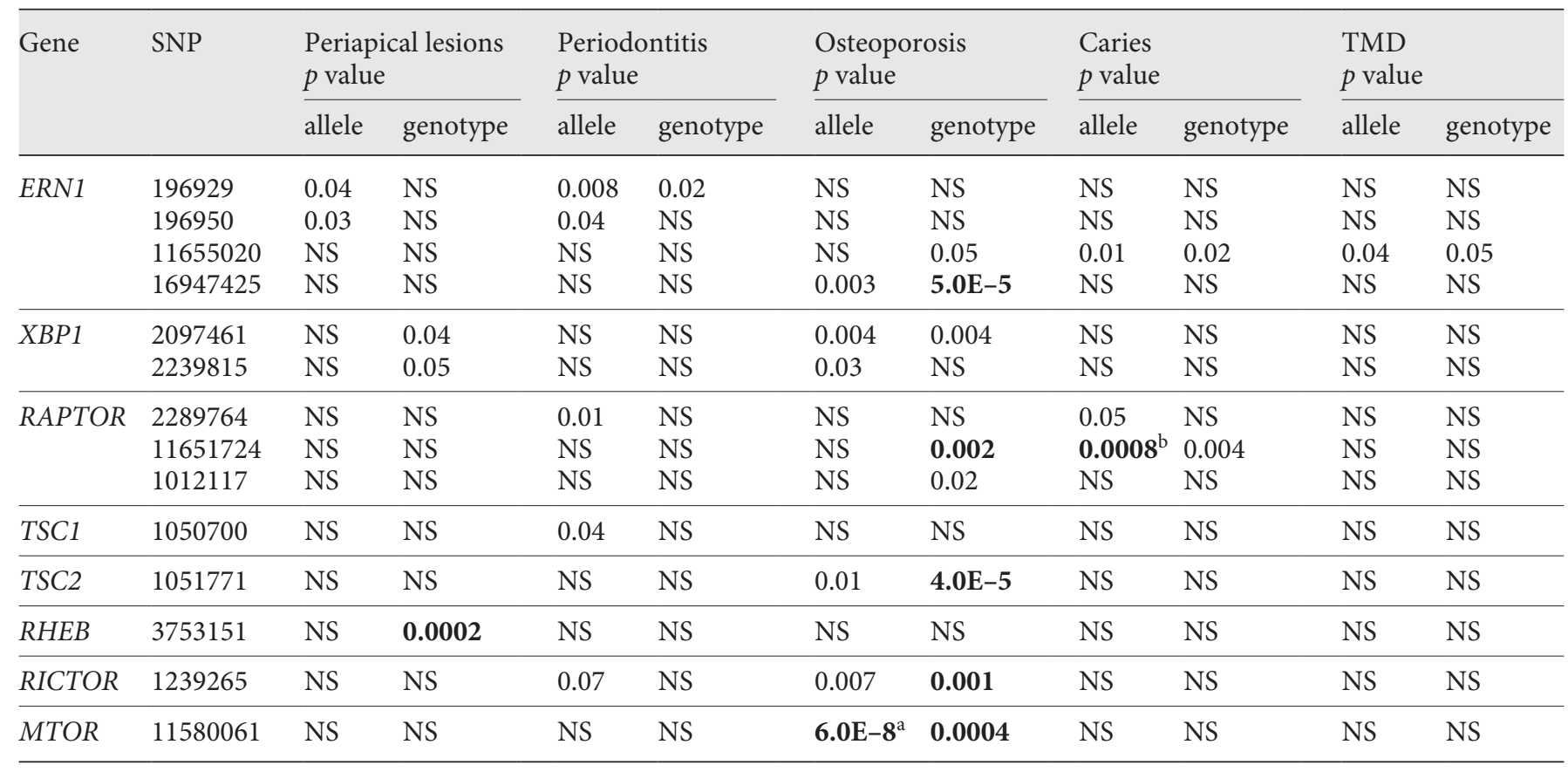

NS, non-statistically significant. Odds ratios (OR) [Koruyucu et al., 2018] and 95\% confidence intervals (CI) were calculated for the significant results $(p<0.002)$ of allele frequency comparisons. ${ }^{a} \mathrm{OR}, 95 \% \mathrm{CI}: 8.51,3.4-21.26 .{ }^{\mathrm{b}} \mathrm{OR}, 95 \% \mathrm{CI}: 1.50,1.18-1.91$.

the general limitation of the work done by us and others, both including candidate gene approaches [Tannure et al., 2012a, b] and genome-wide scan analyses [Shaffer et al., 2011; Wang et al., 2012]. If anybody with any recorded DMFT score is assigned to the disease group, this group will have individuals with very little caries experience (DMFT scores 1 or 2) along with individuals with much higher DMFT scores. We believe a DMFT score of 1 is not under the same influences of a DMFT score of 10 , having one decayed tooth is much less of a severe disease than having 10 teeth affected, for example. Although it may be surprising for many, Pittsburgh is the largest city of the Appalachian region, which is one of the poorest areas of the US, and consequently a region with very poor health indicators, including oral health indicators [Anjomshoaa et al., 2009]. The phenotyping scheme used in our study takes into account ages and distribution of caries experience in the study participants. Individuals with very severe caries experience (DMFT higher than 10 by 20 years of age) demonstrated an association with a genetic variant in RAPTOR. We have previously tested modifying the cut-off thresholds of those definitions and shown that there are no dramatic differences when the threshold is moved slightly (DMFT cut-off 9 in comparison to 10 or 11) [Deeley et al., 2008] [Shimizu et al., 2013], but the limitation continues to be that we lose statistical power when trying to make more distinct groups eliminating intermediate values (comparing caries-free individuals with individuals with DMFT 10 or higher).

This is the first study that has provided evidence for association between a gene in the $m T O R$ pathway and caries. This information may turn out to be relevant for the tissue engineering effort focused on regenerating dentin and the creation of more biocompatible approaches to rehabilitate dental tissue destruction, since RAPTOR particularly regulates cell growth in response to nutrient and insulin levels [Foster et al., 2010].

We found that periodontal disease and osteoporosis were associated with SNPs in ERN1. This result is remarkable, particularly for osteoporosis, due to our study sample size, and should be taken cautiously. ERN1 is involved in the development of secretory cells and organs [Reimold et al., 2000] as well as osteoclastogenesis [Tohmonda et al., 2015], suggesting that ERN1 deficiency may 
Table 3. Summary of all nominal ( $p$ values between 0.05 and 0.002 ) and significant results from the combined analysis of patients with caries, periodontitis, and periapical lesions (bold indicates statistically significant $p$ values under the 0.002 threshold)

\begin{tabular}{|c|c|c|c|c|}
\hline & Gene & SNP & $p$ value & $\begin{array}{l}\text { Genotypic } \\
\text { model }\end{array}$ \\
\hline $\begin{array}{l}\text { Patients with } \\
\text { periodontal } \\
\text { disease and } \\
\text { caries }\end{array}$ & $\begin{array}{l}\text { RAPTOR } \\
\text { RHEB } \\
\text { RICTOR } \\
\text { RAPTOR } \\
\text { RHEB } \\
\text { RAPTOR } \\
\text { RPTOR }\end{array}$ & $\begin{array}{l}\text { rs1012117 } \\
\text { rs1109089 } \\
\text { rs1423688 } \\
\text { rs2374261 } \\
\text { rs2374261 } \\
\text { rs4396582 } \\
\text { rs4396582 }\end{array}$ & $\begin{array}{l}0.05 \\
0.02 \\
0.03 \\
0.02 \\
0.004 \\
0.03 \\
0.03\end{array}$ & $\begin{array}{l}\text { recessive } \\
\text { dominant } \\
\text { recessive } \\
\text { genotype } \\
\text { dominant } \\
\text { genotype } \\
\text { dominant }\end{array}$ \\
\hline $\begin{array}{l}\text { Patients with } \\
\text { periapical } \\
\text { lesions and } \\
\text { caries }\end{array}$ & $\begin{array}{l}\text { RHEB } \\
\text { RHEB } \\
\text { RHEB } \\
\text { RHEB } \\
\text { RHEB } \\
\text { RHEB } \\
\text { ERN1 } \\
\text { ERN1 } \\
X B P 1\end{array}$ & $\begin{array}{l}\text { rs1109089 } \\
\text { rs1109089 } \\
\text { rs1109089 } \\
\text { rs2374261 } \\
\text { rs2374261 } \\
\text { rs2374261 } \\
\text { rs16947425 } \\
\text { rs196950 } \\
\text { rs2239815 }\end{array}$ & $\begin{array}{l}\mathbf{0 . 0 0 2} \\
\mathbf{0 . 0 0 0 6} \\
\mathbf{0 . 0 0 0 7} \\
0.003 \\
\mathbf{0 . 0 0 0 7} \\
\mathbf{0 . 0 0 1} \\
0.04 \\
0.04 \\
0.04\end{array}$ & $\begin{array}{l}\text { genotype } \\
\text { allelic } \\
\text { dominant } \\
\text { genotype } \\
\text { allelic } \\
\text { dominant } \\
\text { recessive } \\
\text { allelic } \\
\text { dominant }\end{array}$ \\
\hline $\begin{array}{l}\text { Patients with } \\
\text { periapical } \\
\text { lesions, } \\
\text { periodontitis, } \\
\text { and caries }\end{array}$ & $\begin{array}{l}\text { RHEB } \\
\text { RHEB } \\
\text { RHEB } \\
\text { RHEB } \\
\text { RHEB } \\
\text { RHEB } \\
\text { ERN1 } \\
\text { RAPTOR }\end{array}$ & $\begin{array}{l}\text { rs1109089 } \\
\text { rs1109089 } \\
\text { rs1109089 } \\
\text { rs2374261 } \\
\text { rs2374261 } \\
\text { rs2374261 } \\
\text { rs16947425 } \\
\text { rs4396582 }\end{array}$ & $\begin{array}{l}0.005 \\
0.003 \\
\mathbf{0 . 0 0 1} \\
\mathbf{0 . 0 0 0 9} \\
\mathbf{0 . 0 0 0 3} \\
\mathbf{0 . 0 0 0 2} \\
0.04 \\
\mathbf{0 . 0 0 1}\end{array}$ & $\begin{array}{l}\text { genotype } \\
\text { allelic } \\
\text { dominant } \\
\text { genotype } \\
\text { allelic } \\
\text { dominant } \\
\text { allelic } \\
\text { allelic }\end{array}$ \\
\hline
\end{tabular}

induce osteopenia/osteoporosis with a slow bone turnover. Recent evidence indicates that the inhibitory effects of TSC1/TSC2 are mediated through TSC2 inactivation of RHEB, and it has been postulated that TSC1/TSC2 complex inhibits mTOR signaling, that pathway is a central regulator of proliferation and cellular growth. Without this functional signaling, cells at the inflammatory sites cannot regenerate, and consequently there will be periodontal tissue destruction or higher predisposition for pulp inflammation even under slow progressing deep caries lesions in dentin. This process will be aggravated by the swollen gingiva and accumulation of plaque.

In this present study, we have done a combined analysis of three phenotypes with the intention of finding a pleiotropic effect of the genes typed in the studied phenotypes. Pleiotropy is when one gene appears to affect more than one unrelated phenotypic trait. Previous studies looking at genetic variants were inconclusive in evidencing an association between caries and periodontitis; none of the gene variants that showed association with periodontitis had been associated with caries before [Nibali et al., 2017]. In our study, both rs2374261 and rs1109089 markers in RHEB showed associations under the dominant model with individuals that had caries and periodontitis. This approach might be efficient in finding pleiotropic genes associated with oral phenotypes and help identify individuals with poor oral health outcomes. We believe that sophisticating phenotype descriptions [Vieira, 2018] and looking for patterns of disease affection [Koruyucu et al., 2018; Weber et al., 2018] based on common underlying mechanisms (i.e., inflammation) are more promising approaches for identifying genes contributing to poor oral health outcomes than genome-wide association studies that use very crude phenotypical descriptions such as "caries-free" versus "caries-affected."

\section{Acknowledgements}

The University of Pittsburgh Dental Registry and DNA Repository provided data and DNA samples for this study. M.B. was supported by the Brazilian Science Without Borders CNPq program. NIH grant R01-DE18914 provided financial support for the project. The funders had no role in study design, data collection and analysis, decision to publish, or preparation of the manuscript.

We thank Piper M. Dizak, Timothy D. Ruff, Navneet Gill, Briana F. Gonsar, and Ryan J. Rylands for their help in genotyping the samples and Benjamin Harrison for helping with the combined analysis. Sincere thanks to Kyle S. Chappel for proofreading and correcting the article.

\section{Disclosure Statement}

The authors declare no potential conflicts of interest with respect to the publication of this article.

\section{Author Contributions}

M.B., K.D., S.K., A.L., R.S., R.M.S., and M.L.W. collected and generated data. M.B., D.G.B., and A.R.V. analyzed data. M.B., R.S., and R.M.S. helped define outcomes to be studied. M.B. wrote the first draft of the manuscript. K.D., S.K., A.L., R.S., R.M.S., M.L.W., D.G.B., P.C.T., A.J.A., and H.O. critically reviewed the manuscript. P.C.T., A.J.A., H.O., and A.R.V. designed the study. P.C.T., A.J.A., and H.O. helped interpret data. A.R.V. defined outcomes to be studied, collected and interpreted data, and generated final draft of the manuscript. 


\section{References}

Anjomshoaa I, Cooper ME, Vieira AR: Caries is associated with asthma and epilepsy. Eur J Dent 2009;3:297-303.

Brown EJ, Albers MW, Shin TB, Ichikawa K, Keith CT, Lane WS, Schreiber SL: A mammalian protein targeted by G1-arresting rapamycin-receptor complex. Nature 1994;369:756758 .

Brugarolas JB, Vazquez F, Reddy A, Sellers WR, Kaelin WG Jr: TSC2 regulates VEGF through mTOR-dependent and -independent pathways. Cancer Cell 2003;4:147-158.

Chapple IL, Bouchard P, Cagetti MG, Campus G, Carra MC, Cocco F, Nibali L, Hujoel P, Laine ML, Lingstrom P, Manton DJ, Montero E, Pitts N, Range H, Schlueter N, Teughels W, Twetman S, Van Loveren C, Van der Weijden F, Vieira AR, Schulte AG: Interaction of lifestyle, behaviour or systemic diseases with dental caries and periodontal diseases: consensus report of group 2 of the joint EFP/ ORCA workshop on the boundaries between caries and periodontal diseases. J Clin Periodontol 2017;44(suppl 18):S39-S51.

Deeley K, Letra A, Rose EK, Brandon CA, Resick JM, Marazita ML, Vieira AR: Possible association of amelogenin to high caries experience in a Guatemalan-Mayan population. Caries Res 2008;42:8-13.

Fan B, Sun YJ, Liu SY, Che L, Li GY: Neuroprotective strategy in retinal degeneration: suppressing ER stress-induced cell death via inhibition of the mTOR signal. Int J Mol Sci 2017; 18:201.

Foster KG, Acosta-Jaquez HA, Romeo Y, Ekim B, Soliman GA, Carriere A, Roux PP, Ballif BA, Fingar DC: Regulation of mTOR complex 1 (mTORC1) by raptor Ser863 and multisite phosphorylation. J Biol Chem 2010;285:8094.

Kim JK, Baker J, Nor JE, Hill EE: mTor plays an important role in odontoblast differentiation. J Endod 2011;37:1081-1085.

Koruyucu M, Kasimoglu Y, Seymen F, Bayram M, Patir A, Ergoz N, Tuna EB, Gencay K, Deeley K, Bussaneli D, Modesto A, Vieira AR: Rethinking isolated cleft lip and palate as a syndrome. Oral Surg Oral Med Oral Pathol Oral Radiol 2018;125:307-312.

Kuchler EC, Feng P, Deeley K, Fitzgerald CA, Meyer C, Gorbunov A, Bezamat M, Reis MF, Noel J, Kouzbari MZ, Granjeiro JM, Antunes LS, Antunes LA, de Abreu FV, Costa MC, Tannure PN, Seymen F, Koruyucu M, Patir A, Vieira AR: Fine mapping of locus Xq25.1-272 for a low caries experience phenotype. Arch Oral Biol 2014;59:479-486.

Letra A, Silva RM, Rylands RJ, Silveira EM, de Souza AP, Wendell SK, Garlet GP, Vieira AR: MMP3 and TIMP1 variants contribute to chronic periodontitis and may be implicated in disease progression. J Clin Periodontol 2012;39:707-716.
Liss J, Evenson P, Loewy S, Ayer WA: Changes in the prevalence of dental disease. Bureau of Economic and Behavioral Research, Council on Dental Health and Health Planning. J Am Dent Assoc 1982;105:75-79.

Menezes-Silva R, Khaliq S, Deeley K, Letra A, Vieira AR: Genetic susceptibility to periapical disease: conditional contribution of MMP2 and MMP3 genes to the development of periapical lesions and healing response. J Endod 2012;38:604-607.

Mercier S, Breuille D, Mosoni L, Obled C, Patureau Mirand P: Chronic inflammation alters protein metabolism in several organs of adult rats. J Nutr 2002;132:1921-1928.

Nibali L, Di Iorio A, Tu YK, Vieira AR: Host genetics role in the pathogenesis of periodontal disease and caries. J Clin Periodontol 2017; 44(suppl 18):S52-S78.

Purcell S, Neale B, Todd-Brown K, Thomas L, Ferreira MA, Bender D, Maller J, Sklar P, de Bakker PI, Daly MJ, Sham PC: PLINK: a tool set for whole-genome association and population-based linkage analyses. Am J Hum Genet 2007;81:559-575.

Qin W, Huang QT, Weir MD, Song Z, Fouad AF, Lin ZM, Zhao L, Xu HHK: Alcohol inhibits odontogenic differentiation of human dental pulp cells by activating mTOR signaling. Stem Cells Int 2017;2017:8717454.

Ranade K, Chang MS, Ting CT, Pei D, Hsiao CF, Olivier M, Pesich R, Hebert J, Chen YD, Dzau VJ, Curb D, Olshen R, Risch N, Cox DR, Botstein D: High-throughput genotyping with single nucleotide polymorphisms. Genome Res 2001;11:1262-1268.

Reimold AM, Etkin A, Clauss I, Perkins A, Friend DS, Zhang J, Horton HF, Scott A, Orkin SH, Byrne MC, Grusby MJ, Glimcher LH: An essential role in liver development for transcription factor XBP-1. Genes Dev 2000;14:152-157.

Ron D, Walter P: Signal integration in the endoplasmic reticulum unfolded protein response. Nat Rev Mol Cell Biol 2007;8:519-529.

Schonthal AH: Endoplasmic reticulum stress: its role in disease and novel prospects for therapy. Scientifica (Cairo) 2012;2012:857516.

Shaffer JR, Wang X, Feingold E, Lee M, Begum F, Weeks DE, Cuenco KT, Barmada MM, Wendell SK, Crosslin DR, Laurie CC, Doheny KF, Pugh EW, Zhang Q, Feenstra B, Geller F, Boyd HA, Zhang H, Melbye M, Murray JC, Weyant RJ, Crout R, McNeil DW, Levy SM, Slayton RL, Willing MC, Broffitt B, Vieira AR, Marazita ML: Genome-wide association scan for childhood caries implicates novel genes. J Dent Res 2011;90:1457-1462.

Shimizu T, Deeley K, Briseno-Ruiz J, Faraco IM Jr, Poletta FA, Brancher JA, Pecharki GD, Kuchler EC, Tannure PN, Lips A, Vieira TC, Patir A, Yildirim M, Mereb JC, Resick JM, Brandon CA, Cooper ME, Seymen F, Costa MC, Granjeiro JM, Trevilatto PC, Orioli IM,
Castilla EE, Marazita ML, Vieira AR: Finemapping of 5q12.1-13.3 unveils new genetic contributors to caries. Caries Res 2013;47: 273-283.

Shuler CF: Inherited risks for susceptibility to dental caries. J Dent Educ 2001;65:10381045.

Tannure PN, Kuchler EC, Falagan-Lotsch P, Amorim LM, Raggio Luiz R, Costa MC, Vieira AR, Granjeiro JM: MMP13 polymorphism decreases risk for dental caries. Caries Res 2012a;46:401-407.

Tannure PN, Kuchler EC, Lips A, Costa Mde C, Luiz RR, Granjeiro JM, Vieira AR: Genetic variation in MMP20 contributes to higher caries experience. J Dent 2012b;40: 381-386.

Tohmonda T, Yoda M, Iwawaki T, Matsumoto M, Nakamura M, Mikoshiba K, Toyama Y, Horiuchi K: IRE1alpha/XBP1-mediated branch of the unfolded protein response regulates osteoclastogenesis. J Clin Invest 2015; 125:3269-3279.

Tsuchiya M, Tye CE, Sharma R, Smith CE, Bartlett JD: XBP1 may determine the size of the ameloblast endoplasmic reticulum. J Dent Res 2008;87:1058-1062.

Vieira AR: Hypothesis-driven versus hypothesisfree approaches to the identification of genes for cleft lip and palate. Arch Oral Biol 2018; 92:88-89.

Vieira AR, Modesto A, Ismail A, Watt R: Summary of the IADR Cariology Research Group Symposium, Barcelona, Spain, July 2010: new directions in cariology research. Caries Res 2012;46:346-352.

Wang X, Shaffer JR, Zeng Z, Begum F, Vieira AR, Noel J, Anjomshoaa I, Cuenco KT, Lee MK, Beck J, Boerwinkle E, Cornelis MC, Hu FB, Crosslin DR, Laurie CC, Nelson SC, Doheny KF, Pugh EW, Polk DE, Weyant RJ, Crout R, McNeil DW, Weeks DE, Feingold E, Marazita ML: Genome-wide association scan of dental caries in the permanent dentition. BMC Oral Health 2012;12:57.

Weber M, Bogstad Sovik J, Mulic A, Deeley K, Tveit AB, Forella J, Shirey N, Vieira AR: Redefining the phenotype of dental caries. Caries Res 2018;52:263-271.

Wei W, Gao Y, Wang C, Zhao L, Sun D: Excessive fluoride induces endoplasmic reticulum stress and interferes enamel proteinases secretion. Environ Toxicol 2013;28: 332-341.

Xia Y, Sun M, Xie Y, Shu R: mTOR inhibition rejuvenates the aging gingival fibroblasts through alleviating oxidative stress. Oxid Med Cell Longev 2017;2017:6292630.

Yoshida H, Matsui T, Yamamoto A, Okada T, Mori K: XBP1 mRNA is induced by ATF6 and spliced by IRE1 in response to ER stress to produce a highly active transcription factor. Cell 2001;107:881-891. 